\title{
Prevalence of Acidovorax citrulli in Commercial Cucurbit Seedlots During 2010-2018 in China
}

\author{
Yanli Tian, ${ }^{1}$ Yuqiang Zhao, ${ }^{2}$ Jiaju Zhou, ${ }^{1}$ Ting Sun, ${ }^{1}$ Xue Luo, ${ }^{1}$ Chet Kurowski, ${ }^{3}$ Weirong Gong, ${ }^{4}$ Baishi Hu, ${ }^{1, \dagger}$ and Ron R. Walcott $5,+$ \\ ${ }^{1}$ College of Plant Protection and Key Laboratory of Integrated Management of Crop Diseases and Pests, Ministry of Education, \\ Nanjing Agricultural University, Nanjing 210095, China \\ ${ }^{2}$ Institute of Botany, Jiangsu Province and Chinese Academy of Sciences (Nanjing Botanical Garden Mem. Sun Yat-Sen), \\ Jiangsu Key Laboratory for the Research and Utilization of Plant Resources, Nanjing 210014, China \\ ${ }^{3}$ HM Clause Inc., Davis, CA 95618, U.S.A. \\ ${ }_{5}^{4}$ Plant Protection and Quarantine Station of JiangSu Province, Nanjing, China \\ ${ }^{5}$ Department of Plant Pathology, University of Georgia, Athens, GA 30602, U.S.A.
}

\begin{abstract}
Acidovorax citrulli is the causal agent of bacterial fruit blotch (BFB), a serious threat to cucurbit fruit and seed production worldwide. In recent years, the BFB has spread to many areas of China, mainly via the inadvertent distribution of contaminated commercial seeds. To assess the prevalence of seedborne $A$. citrulli in commercial watermelon and other cucurbitaceous seedlots in China, a 9-year survey was conducted between 2010 and 2018. A total of 4,839 seedlots of watermelon and other cucurbitaceous species were collected from 13 major seed production areas of China and tested by a semiselective media-based colony PCR technique for A. citrulli. Overall, A. citrulli was detected in $18.00 \%$ $(871 / 4,839)$ of all cucurbitaceous seedlots. The bacterium was detected in $21.59 \%(38 / 176), 19.19 \%(33 / 172), 23.44 \%$ (214/913), $40.76 \%$ (247/606), 13.28\% (85/640), 15.40\% (95/617), 13.25\% (73/551), 8.03\%

(48/598), and $6.71 \%(38 / 566)$ of all commercial seedlots tested from the 2010, 2011, 2012, 2013, 2014, 2015, 2016, 2017, and 2018 growing seasons, respectively. Additionally, the prevalence of A. citrulli in cucurbit seedlots was determined for different seed production areas. The prevalence of $A$. citrulli in cucurbitaceous seedlots produced in Xinjiang, Gansu, Ningxia, Inner Mongolia, and 9 other provinces was $18.76 \%$ (582/3103), 26.34\% (103/391), 21.47\% (82/382), 11.11\% (14/126), and $10.75 \%$ (90/837), respectively. This is the first survey for $A$. citrulli in commercial cucurbit seeds in China, and the relatively high prevalence suggests that commercial seeds represent a substantial source of primary inoculum that can threaten cucurbit seed and fruit production in China.

Keywords: prokaryotes, epidemiology, pathogen survival, small fruits
\end{abstract}

Acidovorax citrulli is the causal agent of bacterial fruit blotch (BFB) (Schaad et al. 2008) (formerly Acidovorax avenae subsp. citrulli $($ Willems et al. 1992) = Pseudomonas pseudoalcaligenes subsp. citrulli (Schaad et al. 1978), a serious threat to cucurbitaceous crop (mainly watermelon [Citrullus lanatus] and muskmelon [Cucumis melo]) production worldwide. The bacterium is seedborne and seed transmitted, and infested/infected seeds represent the most important primary inoculum source for BFB epidemics (Hopkins and Thompson 2002). BFB has caused significant economic losses in cucurbit fruit and seed production worldwide. Yield losses have ranged from $60 \%$ (Latin and Hopkins 1995) in severe epidemics to 80 to $100 \%$ in some regions of China (Jin et al. 2014; Shi and Yu 2015). Unfortunately, little is known about the biology of cucurbit seed infestation by $A$. citrulli under seed production field conditions; hence there are currently no effective strategies to prevent seed infection. Additionally, since BFB management strategies that rely on pathogen exclusion and seed treatments are not $100 \%$ effective, the most effective

${ }^{\dagger}$ Corresponding authors: B. Hu; hbs@njau.edu.cn;

and R. R.Walcott; rwalcott@uga.edu

The first two authors contributed equally to this research.

Funding: This research was supported by the National Key R\&D Program of China (2018YFD0201300) and the Modern Agriculture Industrial Technology System Program of JiangSu, Grant/Award Number: JATS[2018]207.

*The $\boldsymbol{e}$-Xtra logo stands for "electronic extra" and indicates that one supplementary figure is published online.

The author(s) declare no conflict of interest.

Accepted for publication 1 July 2019

(C) 2020 The American Phytopathological Society
BFB control strategy is exclusion of $A$. citrulli by using pathogenfree seeds (Burdman and Walcott 2012).

Perennially, China is the world's leading producer of watermelon and muskmelon (Xu 2011). Large differences between day and night temperatures and low relative humidity make Xinjiang Province, China highly suitable for watermelon and muskmelon cultivation. As a result, Xinjiang Province has become the largest region for watermelon and muskmelon seed production. In particular, Xinjiang represents more than $45 \%$ cucurbitaceous seed production in China (Zhao 2012). In recent years, BFB has occurred in watermelon and muskmelon crops in many provinces in China, including Xinjiang (Zhang and Mo 1996), Gansu (Xue et al. 2009), Ningxia (Jin et al. 2014), Shandong (Zhao et al. 2009), Fujian (Cai et al. 2005), and Guangdong (Ren et al. 2010). The main cause of BFB outbreaks in these provinces has been the use of A. citrulli-infested seeds (An et al. 2013; Zhao 2012).

To enhance cucurbit crop tolerance to Fusarium wilt, grafting and transplanting of greenhouse-grown seedlings have been used for commercial watermelon production worldwide (Nisini et al. 2002). Cucurbit grafting and seedling transplanting became a common practice around 1990 in China (Bie and Present 2009), and currently, with the exception of a few regions, direct seeding in commercial fields has been completely replaced by seedling transplanting. Seed-toseedling transmission of BFB is heavily dependent on high relative humidity (Burdman and Walcott 2012; Rosenberg et al. 2018); hence greenhouse conditions, including high temperatures, high relative humidity, and high plant populations, are conducive to seedling transmission and rapid spread of $A$. citrulli. Additionally, many domestic seed producers do not employ effective disease management strategies to reduce the likelihood of $A$. citrulli seed infestation. Based on local Chinese planting habits and economic pressures, the 3- to 5-year crop rotation with noncucurbit hosts that is widely recommended for BFB management is almost impossible to apply. Hence, the risk of BFB epidemics is higher in China. Since 2003, BFB outbreaks have occurred in greenhouse-grown seedlings in different areas of China (An et al. 2013; Bie and Present 2009; Jin et al. 
2014; Zhao et al. 2009), resulting in widespread disease in grafted cucurbit seedlings and significant economic losses. To reduce the risk of BFB epidemics, only A. citrulli-free seeds should be planted. Hence, it is essential to determine the prevalence of seedborne A. citrulli, especially in major watermelon-growing provinces of China. To assess this, we conducted a 9-year survey for $A$. citrulli in commercial cucurbit crop seedlots in China.

\section{Materials and Methods}

Sampling of commercial cucurbit seedlots. A 9-year seed survey was conducted in China for A. citrulli from 2010 to 2018. A total of 4,839 cucurbit species seedlots were collected from 13 provinces of China and tested for A. citrulli as described below.

About four-fifths of seedlots were sampled from the northwest of China (Xinjiang, Ningxia, Gansu, and Inner Mongolia) due to the high percentage of cucurbitaceous seed production in this region. For each sample, 1,000 seeds were collected.

Seed sample preparation and testing for $\boldsymbol{A}$. citrulli. In order to test for A. citrulli cells that may be in or on seeds, samples ( $n=500$ seeds/lot) were individually "cracked" (not crushed) with a sterilized fingernail clipper (Supplementary Fig. S1) and incubated in $100 \mathrm{ml}$ of PBST (phosphate buffered saline + Tween 20) with agitation on a shaker for $4 \mathrm{~h}$ at room temperature. Subsequently, the seed wash was pelleted by centrifugation at $6,000 \times g$ for $3 \mathrm{~min}$ and the pellet was resuspended in 50-100 $\mu$ l of PBST.

Colony PCR. Colony PCR (Woodman 2008) was used for rapid bacterial identification, which eliminated the need to purify genomic DNA (Pardesi and Tompkins 2015). We routinely used semiselective media-based colony PCR assay with BX-L1/BX-S-R2 primers (Bahar et al. 2008) to detect and recover A. citrulli in seed samples. Briefly, the resuspended pellet was streaked onto 3 plates of TWZ semiselective media $\left(0.5 \%\right.$ peptone, $0.025 \% \mathrm{CaCl}_{2}, 1 \%$ Tween- 80 , $50 \mathrm{mg} /$ liter Berberine, $50 \mathrm{mg} /$ liter cycloheximide, $50 \mathrm{mg} /$ liter 2, 3, 5-triphenyltetrazolium chloride). After incubation at $28^{\circ} \mathrm{C}$ for 48-72 h, 15 cream-colored colonies with red centers were arbitrarily selected from 3 plates for colony PCR. If all three plates had less than 15 colonies, all putative A. citrulli colonies were selected for PCR assay.

Table 1. Results of tests on samples of cucurbit seed lots tested for Acidovorax citrulli collected from various provinces in China in 2010 to 2018

\begin{tabular}{|c|c|c|c|c|c|c|}
\hline \multirow[b]{2}{*}{ Years } & \multirow[b]{2}{*}{ Provinces } & \multirow{2}{*}{$\begin{array}{c}\text { No. of seed lots } \\
\text { surveyed }\end{array}$} & \multirow{2}{*}{$\begin{array}{c}\text { Positive seed lots } \\
\text { (frequency \%) }\end{array}$} & \multicolumn{3}{|c|}{ Positive seed lots/total samples (frequency \%) } \\
\hline & & & & Watermelon & Muskmelon & Rootstock \\
\hline \multirow[t]{2}{*}{2010} & Xinjiang & 176 & 38 & $36 / 164$ & $2 / 12$ & l \\
\hline & Subtotal & 176 & 38 (21.59) & $36 / 164$ (21.95) & $2 / 12(16.67)$ & l \\
\hline \multirow[t]{3}{*}{2011} & Xinjiang & 168 & 32 & $25 / 132$ & $7 / 36$ & / \\
\hline & Ningxia & 4 & 1 & $1 / 4$ & I & I \\
\hline & Subtotal & 172 & 33 (19.19) & 26/136 (19.12) & 7/36 (19.44) & l \\
\hline \multirow[t]{4}{*}{2012} & Xinjiang & 739 & 155 & $140 / 658$ & $8 / 40$ & $7 / 41$ \\
\hline & Ningxia & 34 & 8 & $8 / 34$ & I & I \\
\hline & Gansu & 140 & 51 & $34 / 80$ & l & $17 / 60$ \\
\hline & Subtotal & 913 & $214(23.44)$ & $182 / 772(23.58)$ & $8 / 40(20.00)$ & $24 / 101$ \\
\hline \multirow[t]{12}{*}{2013} & Xinjiang & 417 & 184 & $150 / 364$ & $34 / 52$ & $0 / 1$ \\
\hline & Ningxia & 40 & 23 & $20 / 32$ & $3 / 8$ & / \\
\hline & Gansu & 39 & 21 & $20 / 26$ & $0 / 12$ & $1 / 1$ \\
\hline & Heilongjiang & 8 & 1 & / & $1 / 8$ & / \\
\hline & Jilin & 6 & 1 & l & $1 / 6$ & l \\
\hline & Inner Mongolia & 8 & 1 & l & $1 / 8$ & l \\
\hline & Hebei & 3 & 0 & I & $0 / 3$ & l \\
\hline & Shandong & 17 & 1 & l & / & $1 / 17$ \\
\hline & Anhui & 11 & 6 & l & l & $6 / 11$ \\
\hline & Shanghai & 56 & 8 & / & l & $8 / 56$ \\
\hline & Fujian & 1 & 1 & l & / & $1 / 1$ \\
\hline & Subtotal & 606 & $247(40.76)$ & $190 / 422(45.02)$ & 40/97 (41.24) & $17 / 87$ (19.54) \\
\hline \multirow[t]{12}{*}{2014} & Xinjiang & 345 & 42 & $22 / 264$ & $20 / 81$ & / \\
\hline & Ningxia & 61 & 12 & $12 / 53$ & $0 / 8$ & / \\
\hline & Gansu & 52 & 9 & $8 / 38$ & $1 / 8$ & $0 / 6$ \\
\hline & Heilongjiang & 15 & 2 & $0 / 6$ & $2 / 8$ & $0 / 1$ \\
\hline & Jilin & 11 & 4 & $3 / 8$ & $1 / 3$ & / \\
\hline & Inner Mongolia & 15 & 3 & $2 / 6$ & $1 / 8$ & $0 / 1$ \\
\hline & Hebei & 25 & 4 & $4 / 23$ & $0 / 1$ & $0 / 1$ \\
\hline & Shandong & 34 & 1 & l & l & $1 / 34$ \\
\hline & Shānxi & 11 & 3 & $0 / 1$ & l & $3 / 10$ \\
\hline & Anhui & 50 & 5 & $3 / 28$ & I & $2 / 22$ \\
\hline & Shanghai & 21 & 0 & l & l & $0 / 21$ \\
\hline & Subtotal & 640 & 85 (13.28) & $54 / 427$ (12.65) & 25/117 (21.37) & $6 / 96(6.25)$ \\
\hline \multirow[t]{12}{*}{2015} & Xinjiang & 312 & 48 & $31 / 211$ & $13 / 81$ & $4 / 20$ \\
\hline & Ningxia & 71 & 16 & $12 / 35$ & $4 / 26$ & $0 / 10$ \\
\hline & Gansu & 50 & 9 & $8 / 20$ & $1 / 20$ & $0 / 10$ \\
\hline & Heilongjiang & 25 & 4 & $3 / 12$ & $1 / 13$ & l \\
\hline & Jilin & 10 & 4 & $1 / 2$ & $3 / 8$ & l \\
\hline & Inner Mongolia & 19 & 2 & $2 / 5$ & $0 / 14$ & / \\
\hline & Shandong & 30 & 5 & I & $0 / 2$ & $5 / 28$ \\
\hline & Shānxi & 10 & 0 & $0 / 2$ & I & $0 / 8$ \\
\hline & Anhui & 70 & 3 & $3 / 44$ & I & $0 / 26$ \\
\hline & Shanghai & 20 & 4 & 0 & I & $4 / 20$ \\
\hline & Subtotal & 617 & $95(15.40)$ & 60/331 (18.13) & $22 / 164(13.41)$ & $13 / 122(10.66)$ \\
\hline & & & & & & don next page) \\
\hline
\end{tabular}


Each PCR reaction mixture contained $1.5 \mathrm{mM} \mathrm{MgCl}_{2}, 0.2 \mathrm{mM}$ $\mathrm{dNTP}, 300 \mathrm{nM}$ of each primer, and $1 \mathrm{U}$ of Taq polymerase (TaKaRa, Dalian, China) in $25 \mu 1$ PCR reaction mixture. Each colony (approximately $1 \mathrm{~mm}$ in diameter) was picked up with a sterilized toothpick and directly transferred to a PCR tube. PCR was conducted in an Eppendorf Mastercycler System 2700 (Eppendorf, Germany) using the following thermal cycle program: one cycle of $95^{\circ} \mathrm{C}$ for $1 \mathrm{~min}$; 35 cycles of $94^{\circ} \mathrm{C}$ for $35 \mathrm{~s}, 68.1^{\circ} \mathrm{C}$ for $35 \mathrm{~s}$, and $72^{\circ} \mathrm{C}$ for $45 \mathrm{~s}$, and incubation at $72^{\circ} \mathrm{C}$ for $5 \mathrm{~min}$. The reaction was then immediately cooled to $10^{\circ} \mathrm{C}$, and $10 \mu \mathrm{l}$ of each PCR reaction mixture was analyzed by electrophoresis on a $2.5 \%$ agarose gel at $120 \mathrm{~V}$ for 10 min. A seed sample was considered to be positive for $A$. citrulli if one or more colonies were positive by PCR (i.e., yielded the expected amplicon). If no A. citrulli-like colonies developed on the three TWZ plates, or if none of the selected colonies were positive by PCR assay, the seed sample was considered to be negative for A. citrulli.

Detection of $\boldsymbol{A}$. citrulli within seeds. In order to determine if A. citrulli cells were present inside or on the surface of seeds in PCR-positive cucurbit seedlots, lots (one each of watermelon, muskmelon, and pumpkin or bottle gourd rootstock) that tested positive for A. citrulli were selected. Samples ( $n=100$ seeds/lot) from each lot were surface disinfested as described below to eradicate surface microflora. Briefly, each seedlot was soaked in $30 \%$ $\mathrm{HCl}$ for $10 \mathrm{~min}$, washed three times in $\mathrm{ddH}_{2} \mathrm{O}$ for $5 \mathrm{~min}$, and then air-dried at room temperature for $1 \mathrm{~h}$. Each seed was cracked open with a fingernail clipper as described above, and incubated in $500 \mu \mathrm{l}$ of PBST in a sterilized microcentrifuge tube for $4 \mathrm{~h}$ at room temperature. Subsequently, the seed wash was pelleted by centrifugation at $6,000 \times g$ for $3 \mathrm{~min}$, resuspended in $10 \mu \mathrm{l}$ of PBST, and spread onto one plate of TWZ semiselective media. Putative A. citrulli colonies were tested by colony PCR assay as described above.

\section{Results}

Prevalence of $A$. citrulli in commercial cucurbitaceous seeds in China from 2010 to 2018. Out of 4,839 commercial cucurbit seed samples tested for $A$. citrulli between 2010 and 2018, 68.71\% were watermelon, $19.37 \%$ were muskmelon, and $11.92 \%$ were rootstock (Table 1, Fig. 1). Overall, $18.00 \%(871 / 4,839)$ of the samples were positive for A. citrulli when tested by the semiselective agar enrichment followed by colony PCR assay. Based on cucurbit species tested, $18.92 \%(629 / 3,325), 17.93 \%$ (168/937), and $12.82 \%(74 / 577)$ of watermelon, muskmelon, and rootstock seedlots, respectively, tested positive for $A$. citrulli (Table 1, Fig. 2). The prevalence of $A$. citrulli-infested seedlots was highest in 2013 (40.76\%, 247/606). Between 2010 and 2012, 3 years showed a 19.19-23.44\% prevalence of A. citrulli-infested seedlots. Interestingly, between 2014 and 2018, 5 years showed a $6.41-15.40 \%$ prevalence of $A$. citrulliinfested seedlots.

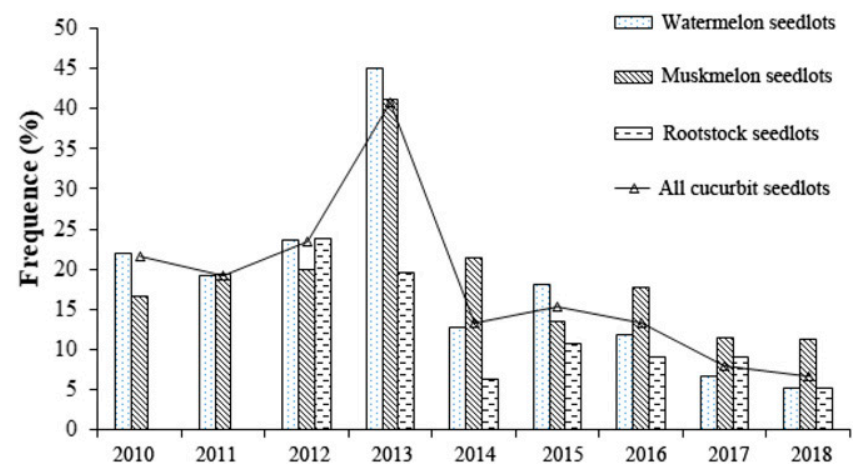

Fig. 1. Prevalence of Acidovorax citrulli in commercial cucurbitaceous seeds in China from 2010 to 2018.

Table 1. (Continued from previous page)

\begin{tabular}{|c|c|c|c|c|c|c|}
\hline \multirow[b]{2}{*}{ Years } & \multirow[b]{2}{*}{ Provinces } & \multirow{2}{*}{$\begin{array}{l}\text { No. of seed lots } \\
\text { surveyed }\end{array}$} & \multirow{2}{*}{$\begin{array}{l}\text { Positive seed lots } \\
\text { (frequency \%) }\end{array}$} & \multicolumn{3}{|c|}{ Positive seed lots/total samples (frequency \%) } \\
\hline & & & & Watermelon & Muskmelon & Rootstock \\
\hline \multirow[t]{9}{*}{2016} & Xinjiang & 302 & 42 & $25 / 201$ & $15 / 80$ & $2 / 21$ \\
\hline & Ningxia & 66 & 13 & $7 / 31$ & $5 / 25$ & $1 / 10$ \\
\hline & Gansu & 60 & 6 & $2 / 30$ & $3 / 20$ & $1 / 10$ \\
\hline & Heilongjiang & 27 & 2 & $0 / 12$ & $2 / 15$ & I \\
\hline & Jilin & 14 & 2 & $0 / 2$ & $2 / 12$ & / \\
\hline & Inner Mongolia & 22 & 3 & $1 / 11$ & $2 / 11$ & / \\
\hline & Anhui & 50 & 4 & $2 / 24$ & l & $2 / 26$ \\
\hline & Shanghai & 10 & 1 & / & / & $1 / 10$ \\
\hline & Subtotal & 551 & $73(13.25)$ & $37 / 311(11.90)$ & 29/163 (17.79) & 7/77 (9.09) \\
\hline \multirow[t]{11}{*}{2017} & Xinjiang & 342 & 27 & $15 / 271$ & $10 / 61$ & $2 / 10$ \\
\hline & Ningxia & 56 & 5 & $2 / 35$ & $3 / 20$ & $0 / 1$ \\
\hline & Gansu & 20 & 2 & $1 / 10$ & $1 / 10$ & I \\
\hline & Heilongjiang & 26 & 3 & $1 / 10$ & $2 / 16$ & I \\
\hline & Jilin & 20 & 1 & $1 / 12$ & $0 / 8$ & I \\
\hline & Liaoning & 56 & 4 & $2 / 17$ & $2 / 39$ & I \\
\hline & Inner Mongolia & 30 & 2 & $1 / 15$ & $1 / 12$ & $0 / 3$ \\
\hline & Shandong & 18 & 2 & $0 / 2$ & 1 & $2 / 16$ \\
\hline & Anhui & 25 & 2 & $1 / 5$ & I & $1 / 20$ \\
\hline & Shanghai & 5 & 0 & I & I & $0 / 5$ \\
\hline & Subtotal & 598 & $48(8.03)$ & $24 / 377(6.37)$ & $19 / 166(11.45)$ & $5 / 55(9.09)$ \\
\hline \multirow[t]{11}{*}{2018} & Xinjiang & 302 & 14 & $7 / 249$ & $7 / 51$ & $0 / 2$ \\
\hline & Ningxia & 50 & 4 & $2 / 28$ & $2 / 20$ & $0 / 2$ \\
\hline & Gansu & 30 & 5 & $2 / 18$ & $3 / 10$ & $0 / 2$ \\
\hline & Heilongjiang & 29 & 2 & $1 / 16$ & $1 / 13$ & / \\
\hline & Jilin & 30 & 3 & $2 / 12$ & $1 / 18$ & l \\
\hline & Liaoning & 36 & 3 & $1 / 16$ & $2 / 20$ & I \\
\hline & Inner Mongolia & 32 & 3 & $3 / 19$ & $0 / 10$ & $0 / 3$ \\
\hline & Shandong & 22 & 2 & $1 / 12$ & / & $1 / 10$ \\
\hline & Anhui & 35 & 2 & $1 / 15$ & I & $1 / 20$ \\
\hline & Subtotal & 566 & $38(6.71)$ & $20 / 385(5.19)$ & $16 / 142(11.27)$ & 2/39 (5.13) \\
\hline & Total & 4839 & $871(18.00)$ & $629 / 3325(18.92)$ & $168 / 937(17.93)$ & $74 / 577(12.82)$ \\
\hline
\end{tabular}


Prevalence of $A$. citrulli in commercial cucurbitaceous seeds in different seed production areas in China. The majority of cucurbit seeds tested in this survey were produced in Xinjiang Province (64.12\%); while $8.08 \%$ were produced in Gansu Province, $7.89 \%$ were produced in Ningxia Province, $2.60 \%$ were produced in Inner Mongolia, and $17.31 \%$ were produced in 9 other provinces (Fig. 3, Table 1). The prevalence of $A$. citrulli-infested seedlots was highest in Gansu Province $(26.34 \%, 391 / 1,031)$ followed by Ningxia (21.47\%, 82/382), Xinjiang (18.76\%, 582/3103), and Inner Mongolia $(11.11 \%, 14 / 126)$. The prevalence of $A$. citrulli in seedlots from the other 9 provinces combined was 10.75\% (90/837) (Fig. 3, Table 1).

Frequency of detection of $A$. citrulli in internal cucurbits seed tissues. The frequencies with which we detected $A$. citrulli in the internal tissues of seeds were $2 \%(2 / 100), 6 \%(6 / 100)$, and $3 \%$ (3/100) for watermelon, muskmelon, and pumpkin and bottle gourd rootstock samples, respectively.

\section{Discussion}

BFB has heavy potential for economic losses in Chinese cucurbit fruit and seed production systems. While infested seeds represent a critically important source of primary inoculum for BFB outbreaks, there have been no previous attempts to determine the prevalence of A. citrulli in commercial cucurbit seedlots in China, nor to determine if this inoculum source is correlated to the frequency of BFB outbreaks. Accordingly, this is the first study to survey the prevalence of $A$. citrulli in commercial cucurbit seeds in China. Overall, we determined that between 2010 and $2018,18.00 \%$ of cucurbit seed samples were infested with the pathogen.

In addition to watermelon and muskmelon, other cucurbitaceous crop species are susceptible to A. citrulli infection, and their seeds can be infested with, and transmit, BFB to seedlings (Hopkins and Thompson 2002). Of the 577 pumpkin and bottle gourd rootstock seed samples collected, $10.74 \%$ were positive for $A$. citrulli, respectively. In July 2012, we demonstrated that $A$. citrulli transmitted from pumpkin rootstock seeds by grafting can cause watermelon seedling blight (Tian et al. 2013). These results indicated that infected rootstock cucurbits could be significant inoculum sources of $A$. citrulli.

In China, some cucurbit varieties are produced specifically for domestic markets. For example, in Gansu and Ningxia provinces, Lvbao and Jincheng varieties of watermelon are heavily produced for local consumption. Since there is high demand for these varieties, it is difficult to implement the 3- to 5-year crop rotations that are recommended for BFB management in these regions. Unfortunately, watermelon seedlots of Lvbao and Jincheng varieties were both produced in regions of Gansu (Xue et al. 2009) and Ningxia (Jin et al. 2014) that have a history of BFB outbreaks. In regions where A. citrulli is prevalent, the risk of BFB development is high when environmental conditions are favorable for disease development. In this study, the majority of watermelon seed samples collected from Gansu and Ningxia provinces was comprised of Lvbao (102/144, $70.83 \%)$ and Jincheng (106/123, 86.18\%) varieties, respectively. The frequencies of $A$. citrulli-infested seedlots of watermelon varieties Lvbao and Jincheng were 35.29\% (36/102) and 33.02\% (35/ 106), which were more than those observed in Xinjiang Province. Data from the current study suggest that cucurbit seeds produced in regions with a history of BFB have increased risk of seed infestation with $A$. citrulli. Therefore, crop rotations with noncucurbit hosts, in addition to seed testing, should be strictly implemented to mitigate the effect of $A$. citrulli in these regions.

We observed that the frequency of $A$. citrulli-infested cucurbit seedlots increased between 2010 and 2013, but decreased by more than $40 \%$ after 2014. Many factors may have contributed to the low incidence of $A$. citrulli-infested seedlots after 2014. However, the most important factor may have been a combination of the recognition of the economic impact of BFB and use of antimicrobial seed treatments. In recent years, many seed producers relied on local farmers to produce cucurbit seeds. However, all of the fruits, including those showing BFB symptoms, were used by some farmers to increase seed yield and profit. In 2013, (40.76\%) (247/606) of the commercial cucurbit seedlots collected in China were positive for A. citrulli. At the same time, BFB outbreaks were reported in many regions of China, including Liaoning (An et al. 2013), Ningxia (Jin et al. 2014), and Shandong (Zhang et al. 2014). At this time, many small seed companies and farmers acknowledged the importance of BFB and subsequently started discarding rotten and symptomatic fruits from seed production fields and implementing seed treatments, including thermotherapy, $\mathrm{NaOCl}, \mathrm{HCl}$, and peroxyacetic acid. During 2014 to 2018, the prevalence of A. citrulli-infested seeds was dramatically reduced, and we speculate that improved sanitation and seed treatments were in part responsible for this reduction.

We observed that 2 to $6 \%$ of the tested cucurbit seed samples collected in China were internally infected with A. citrulli. This suggests that externally applied seed treatments alone will not completely eliminate seedborne A. citrulli inoculum in China. Highly effective treatments must be able to penetrate the seed coat to completely eliminate deep-seated bacterial cells (Burdman and Walcott 2012; Dutta et al. 2016). Hopkins et al. (1996) reported that fermentation of seeds in watermelon juice for $24-48 \mathrm{~h}$, followed by treatment with $1 \% \mathrm{HCl}$ for $15 \mathrm{~min}$, eliminated BFB seedling transmission. Additionally, they reported that treatment with peroxyacetic acid completely eliminated A. citrulli from naturally infested watermelon and melon seeds (Hopkins et al. 2003). On the other hand, Dutta et al. demonstrated that externally applied peroxyacetic acid could not eliminate $A$. citrulli from seeds that were infected by pistil invasion, which led to the deposition of bacterial cells in the embryo of the seed (Dutta et al. 2012, 2016). More detailed studies are needed to prove that seedlots

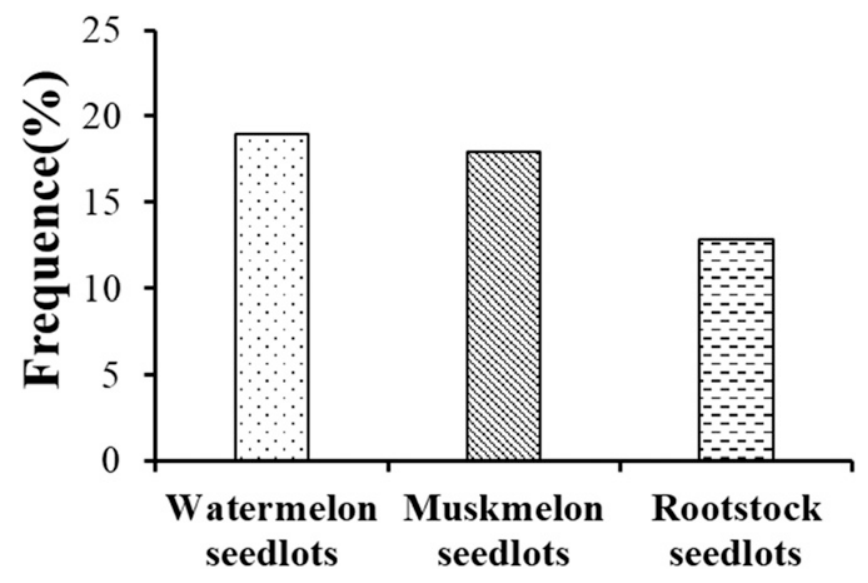

Fig. 2. Prevalence of Acidovorax citrulli in different commercial cucurbitaceous seeds in China.

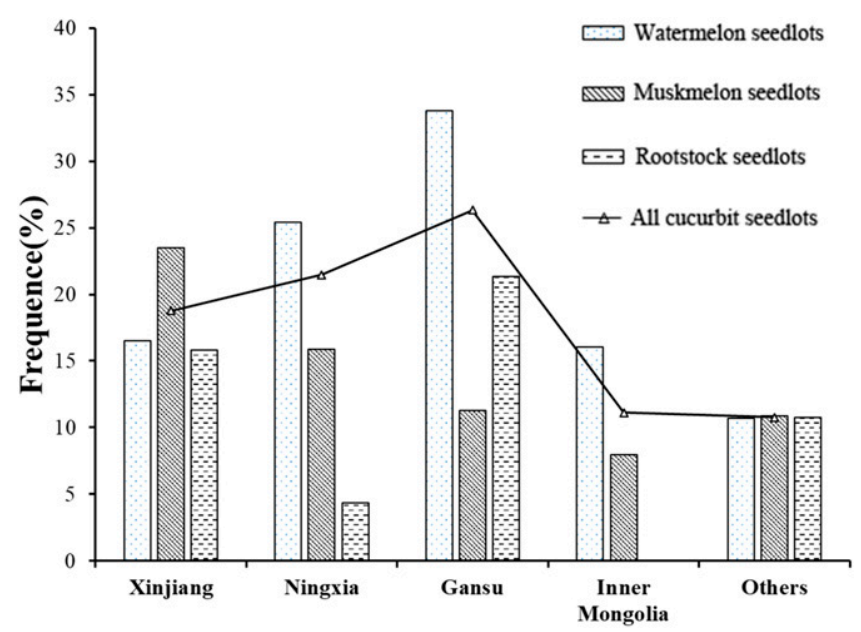

Fig. 3. Prevalence of Acidovorax citrulli in commercial cucurbitaceous seeds in different seed production areas in China. 
infected/infested with $A$. citrulli are not due to cross contamination during harvesting or processing in China. While no chemical or physical seed treatments are $100 \%$ effective at eradicating $A$. citrulli, seed treatments can significantly reduce $\mathrm{BFB}$ seed-to-seedling transmission. Nonetheless, producing A. citrulli-free cucurbit seed is the first step toward effective BFB management in China. Therefore, to reduce the risk of seed infestation in commercial seed production, only symptomless cucurbit fruits should be harvested, and in fact, seeds should not be harvested from fields in which symptomatic fruits and foliage have been observed. In summary, based on our survey results, $A$. citrulli-infested seed is a serious threat to the watermelon and muskmelon fruit and seed industries in China and must be reduced through comprehensive, zero-tolerance strategies in seed production fields, seed health testing, and seed treatments.

\section{Acknowledgments}

We thank Li Jian-qiang from China Agricultural University for providing partial seedlots.

\section{Literature Cited}

An, X., Sun, B., Liu, Z., Yang, Y., and Zhao, T. 2013. Occurrence of watermelon bacterial fruit blotch in Liaoning. China Vegetable 23:22-23.

Bahar, O., Efrat, M., Hadar, E., Dutta, B., Walcott, R. R., and Burdman, S. 2008. New subspecies-specific polymerase chain reaction-based assay for the detection of Acidovorax avenae subsp. citrulli. Plant Pathol. 57:754-763.

Bie, Z., and Present, S. 2009. Problem and countermeasures of grafted cucurbit seedlings production in China. J. Changjiang Vegetables China 2:1-5.

Burdman, S. and Walcott R. 2012. Acidovorax citrulli: Generating basic and applied knowledge to tackle a global threat to the cucurbit industry. Mol. Plant Pathol. 13:805-815.

Cai, X. Q., Huang, Y. Y., Yang, J. Z., Chen, J., Cai, G. L., and Hu, F. P. 2005. Pathogen identification of bacterial fruit blotch of watermelon in Fujian. J. Fujian Agric. For. Univ. China 34:434-437.

Dutta, B., Schneider, R. W., Robertson, C. L., and Walcott, R. R. 2016. Embryo localization enhances the survival of Acidovorax citrulli in watermelon seeds. Phytopathology. 106:330-338.

Dutta, B., Scherm, H., Gitaitis, R. D., and Walcott, R. R. 2012. Acidovorax citrulli seed inoculum load affects seedling transmission and spread of bacterial fruit blotch of watermelon under greenhouse conditions. Plant Dis. 96:705-711.

Hopkins, D. L., Cucuzza, J. D., and Watterson, J. C. 1996. Wet seed treatments for the control of bacterial fruit blotch of watermelon. Plant Dis. 80:529.

Hopkins, D. L., and Thompson, C. M. 2002. Seed transmission of Acidovorax avenae subsp. citrulli in cucurbits. HortScience 37:924-926.

Hopkins, D. L., Thompson, C. M., Hilgren, J., and Lovic, B. 2003. Wet seed treatment with peroxyacetic acid for the control of bacterial fruit blotch and other seedborne diseases of watermelon. Plant Dis. 87:1495-1499.
Jin, M., Zhao, Z., Gao, Y., and Yang, N. 2014. Occurrence and control measures of watermelon fruit blotch in Litong District in Wuzhong Municipality. Ningxia J. Agric. Fores. China 55:33-34.

Latin, R. X., and Hopkins, D. L. 1995. Bacterial fruit blotch of watermelon. The hypothetical exam question becomes reality. Plant Dis. 79:761-765.

Nisini, P. T., Colla, G., Granati, E., Temperini, O., and Saccardo, F. 2002. Rootstock resistance to Fusarium wilt and effect on fruit yield and quality of two muskmelon cultivars. Sci. Hortic. (Amsterdam) 93:281-288.

Pardesi, B., and Tompkins, G. R. 2015. Colony polymerase chain reaction of heme-accumulating bacteria. Anaerobe 32:49-50.

Ren, X. P., Li, X. N., Wang, L., Sun, J. X., Wu, J. L., and Liu, Q. G. 2010 Identification for pathogen of bacterial fruit blotch of watermelon in Guangdong Province. Hua Nan Nong Ye Da Xue Xue Bao 31:40-43.

Rosenberg, T., Salam, B. B., and Burdman, S. 2018. Association between loss of type iv pilus synthesis ability and phenotypic variation in the cucurbit pathogenic bacterium Acidovorax citrulli. Mol. Plant-Microbe Interact. 31:548-559.

Schaad, N. W., Postnikova, E., Sechler, A., Claflin, L. E., Vidaver, A. K., Jones, J. B., Agarkova, I., Ignatov, A., Dickstein, E., and Ramundo, B. A. 2008 Reclassification of subspecies of Acidovorax avenae as A. avenae (Manns 1905) emend, A. cattleyae (Pavarino, 1911) comb. nov., A. citrulli (Schaad et al., 1978) comb. nov., and proposal of A. oryzae sp. nov. Syst. Appl. Microbiol. 31:434-446.

Schaad, N. W., Sowell, G., Goth, R. W., Colwell, R. R., and Webb, R. E. 1978 Pseudomonas pseudoalcaligenes subsp. citrulli. nov. Int. J. Syst. Bacteriol. 28:117-125.

Shi, J., and Yu, L. 2015. Occurrence and control of watermelon bacterial fruit blotch. China Agric. Inf. 2:114-115.

Tian, Y. L., Zhao, Y. Q., Hu, B. S., and Liu, F. Q. 2013. First report of seedling blight of watermelon caused by Acidovorax citrulli transmitted from rootstock of pumpkin in China. Plant Dis. 97:420.

Willems, A., Goor, M., Thielemans, S., Gillis, M., Kersters, K., and De Ley, J. 1992. Transfer of several phytopathogenic Pseudomonas species to Acidovorax as Acidovorax avenae subsp. avenae subsp. nov., comb. nov., Acidovorax avenae subsp. citrulli, Acidovorax avenae subsp. cattleyae, and Acidovorax konjaci. Int. J. Syst. Bacteriol. 42:107-119.

Woodman, M. E. 2008. Direct PCR of intact bacteria (colony PCR). Curr. Protoc. Microbiol. May. Appendix 3 (Appendix):3D.

$\mathrm{Xu}, \mathrm{Y} .2011$. Watermelon industry in China. Chin. Cucurbits Vegetables 5:71-73.

Xue, L., Yang, C. D., Chen, X. R., Jia, Y. C., and Luo, D. L. 2009. Identification of the bacterial blotch of watermelon in Jiuquan district of Gansu Province. China Plant Prot. 35:53-57.

Zhang, X. L., and Mo, G. H. 1996. Occurrence of watermelon bacterial fruit blotch and identification of its pathogens in Xin Jiang. Xinjiang Agric. Sci. China 4: 183-184.

Zhang, Y., Qi, J., Zhang, B., Li, L., Xu, Z., Zheng, J., and Li, C. 2014. Pathogen identification of watermelon bacterial fruit blotch in Shandong Province. Shandong Agric. Sci. China 46:83-85.

Zhao, T. C. 2012. Watermelon industry in China. Chin. Cucurbits Vegetables 25: $70-71$.

Zhao, T. C., Zhao, H. H., and Wang, H. S. 2009. Occurrence of watermelon bacterial fruit blotch and identification of its pathogens in Shandong. Plant Prot. China 35:170-171. 